\title{
WHAT ARE WE MISSING? DESTINATION MARKETING AND HOSPITALITY OF A CULTURAL DESTINATION IN BRAZIL FROM THE STAKEHOLDERS' PERSPECTIVE
}

\author{
Mariana de Freitas Coelho \\ PHD in Business \\ Federal university of Viçosa, Minas Gerais, Brazil \\ marifcoelho@gmail.com \\ Elizabeth Kyoko Wada \\ Post Doctorade in Tourism \\ Universidade Anhembi Morumbi , São Paulo, SP, Brazil \\ ewada@uol.com.br \\ Ana Cláudia Azevedo \\ PHD in Business \\ anaazevedo@ufv.br
}

\begin{abstract}
Study objective: This study aims to understand the marketing activities and tourist profile of a cultural tourism destination from the stakeholders' perspective.

Methodology/approach: Using a mixed-method approach, we collected data through in-depth interviews with stakeholders from Ouro Preto, in Minas Gerais in Brazil, in 2013 and 2019. We carried out a survey of 396 local tourists to understand their socioeconomic profile.

Originality/Value: Our central argument is that although the destination has renamed its attractions, the stakeholders need to work together to innovate and provide novelty and surprises for excursionists and international travelers, without forgetting the local people (residents, employees, hosts, and guests). In addition, investigating stakeholders could provide insights into how the trade could surprise tourists by developing new hospitality programs.

Main results: The results showed there are at least four types of tourists in Ouro Preto: historical-cultural tourists, fraternity tourists, regional visitors, and the international tourists. This last group has not been appropriately addressed by the destination marketing organizations, such as restaurants, hotels, travel agencies, and government. The main findings can be grouped into five areas: i) marketing promotion activities, ii) new technologies, iii) branding and marketing plan, iv) product development, and v) new and solved problems.

Theoretical/methodological contributions: The main contribution of this study is its longitudinal analysis of the destination. This is still incipient in tourism research and helps in evaluating how tourism activity is changing over the years. It also points out possible ways to promote not only Ouro Preto but other Brazilian destinations internationally.
\end{abstract}

Keywords: Stakeholders. Destination marketing and branding. Destination marketing organizations. Hospitality. Cultural tourism.

\section{Cite como}

American Psychological Association (APA)

Coelho, M. F., Wada, E. K., \& Azevedo, A. C. (2021, maio/ago.). What are we missing? destination marketing and hospitality of a cultural destination in Brazil from the stakeholders' perspective. PODIUM Sport, Leisure and Tourism Review, São Paulo, 10(2), 191-215. https://doi.org/10.5585/podium.v10i2.17014. 


\title{
O QUE NOS FALTA? MARKETING DE DESTINO TURÍSTICO E HOSPITALIDADE EM UM DESTINO CULTURAL BRASILEIRO SOB A PERSPECTIVA DOS STAKEHOLDERS
}

\section{Resumo}

Objetivo do estudo: o objetivo deste estudo é compreender as atividades de promoção de marketing e o perfil do turista de um destino cultural na perspectiva dos stakeholders.

Metodologia/Abordagem: por meio de uma abordagem mista, foram realizadas entrevistas em profundidade, em 2013 e 2019, com os stakeholders do município de Ouro Preto, Minas Gerais, Brasil. Para se entender o perfil socioeconômico dos turistas, aplicou-se um survey a 396 turistas locais.

Originalidade/Relevância: o argumento central é que, embora o destino tenha atrativos renomeados, os stakeholders precisam de trabalhar juntos para inovar, fornecendo novas experiências para excursionistas e viajantes internacionais, sem esquecer a população local. Além disso, investigar o repertório de seus stakeholders pode trazer insights sobre como o trade poderia surpreender os turistas, desenvolvendo também programas de hospitalidade.

Principais resultados: os resultados mostram que existem pelo menos quatro tipos de turistas em Ouro Preto, os turistas histórico-culturais, os turistas de repúblicas, os visitantes regionais e os turistas internacionais, que não foram devidamente contemplados pelas organizações de marketing de destino, como restaurantes, hotéis, agências de viagem e governo. As principais conclusões do estudo podem ser agrupadas em 5 áreas: i) atividades de promoção de marketing, ii) novas tecnologias, iii) plano de marketing e branding, iv) desenvolvimento de produtos e, v) problemas novos e resolvidos.

Contribuições teóricas/metodológicas: a principal contribuição é a análise longitudinal do destino, ainda incipiente nas pesquisas em turismo, mas que pode ajudar a compreender as mudanças no destino ao longo do tempo. Também são apontadas possíveis formas de promover destinos internacionalmente, não apenas Ouro Preto, mas também outros destinos brasileiros similares.

Palavras-chave: Stakeholders. Marketing de destino e branding. Organizações de marketing de destino. Hospitalidade. Turismo cultural.

\section{¿LO QUÉ NOS FALTA? MARKETING DE DESTINO TURÍSTICO Y HOSPITALIDAD DE UN DESTINO CULTURAL EN BRASIL DESDE LA PERSPECTIVA DE LOS STAKEHOLDERS}

\begin{abstract}
Resumen
Objetivo del estudio: el objetivo de este estudio es comprender las actividades de promoción de marketing y el perfil del turista de un destino cultural desde la perspectiva de los interesados.

Metodología/Enfoque: a través de un enfoque mixto, se realizaron entrevistas en profundidad en 2013 y 2019 con partes interesadas del municipio de Ouro Preto, Minas Gerais, Brasil. Para comprender el perfil socioeconómico de los turistas, se aplicó una encuesta a 396 turistas locales.

Originalidad / Relevancia: el argumento central es que, aunque el destino tiene atracciones de renombre, las partes interesadas deben trabajar juntas para innovar, proporcionando nuevas experiencias para los excursionistas y viajeros internacionales, sin olvidar a la población local. Además, investigar el repertorio de sus partes interesadas puede aportar información sobre cómo el comercio podría sorprender a los turistas, al tiempo que desarrolla programas de hospitalidad.

Resultados principales: los resultados muestran que hay al menos cuatro tipos de turistas en Ouro Preto, turistas históricos y culturales, turistas de repúblicas, visitantes regionales y turistas internacionales, que no han sido cubiertos adecuadamente por las organizaciones de marketing de destino, como restaurantes, hoteles, agencias de viajes y gobierno. Las principales conclusiones del estudio se pueden agrupar en 5 áreas: i) actividades de promoción de marketing, ii) nuevas tecnologías, iii) plan de marketing y marca, iv) desarrollo de productos $\mathrm{y}, \mathrm{v}$ ) problemas nuevos y resueltos.

Contribuciones teóricas/metodológicas: la contribución principal es el análisis longitudinal del destino, que aún es incipiente en la investigación turística y ayuda a evaluar cómo la actividad turística está cambiando a lo largo de los años. También se señalan las posibles formas de promover destinos a nivel internacional, no solo Ouro Preto, sino también otros destinos similares en Brasil.
\end{abstract}

Palabras clave: Partes interesadas. Marketing de destino y branding. Organizaciones de marketing de destino. Hospitalidad. Turismo cultural. 


\section{Introduction}

Tourism marketing is still under development in the theoretical body of marketing knowledge. Although several articles (Flores, Cavalcante, \& Raye, 2013; Ocke \& Ikeda, 2013; Donilcar \& Ring, 2014; Hudson et al., 2019) have addressed the theme, a tourism marketing theory has not yet been substantiated, although it is known to involve several elements (attractiveness, competitiveness, destination branding, marketing mix, and others).

The growing competitiveness between tourist destinations has attracted greater academic and marketing attention to the topic of tourism marketing (Martínez-Román et al., 2015). Destinations are the basis of most tourism activities and they represent the tourism product (Kozak \& Andreu, 2006) and where the tourism experiences occur (Coelho \& Gosling, 2017). Tourism marketing promotion should emphasize the destination as a whole, rather than each element of the tourism product and its complementary services (Falkner, 2001). Capturing the consumers' imagination requires a succinct message that focuses on one or a few brand associations (Pike, 2005).

The complexity of tourism and the number of stakeholders make destination marketing a real challenge. Stakeholders are "any group or individual who can affect or is affected by the achievement of the organization's objectives" (Freeman, 1984:46). Managing tourism-related institutions, organizations, resources, and individuals demands an understanding the dynamics and potential of the destination. This study discusses the marketing promotion of one particular cultural destination. Although Brazil is recognized as an exotic tourism destination, it still attracts few foreigners when compared to other similar destinations, and the demand mainly involves domestic travel (Théry, 2015). Therefore, this study is important as it reflects the challenges of promoting Brazil according to the perceptions of stakeholders in Ouro Preto.

Ouro Preto is a historical city located in Minas Gerais State, about $400 \mathrm{~km}$ from Rio de Janeiro and $630 \mathrm{~km}$ from São Paulo. It is known for its baroque churches, cobblestone streets, and colonial architecture, and it forms part of a region of other historical cities, such as Congonhas, Mariana, São João del Rei, and Tiradentes. It is also close to Belo Horizonte, the capital of Minas Gerais State (Figure 1). 
Figure 1 - Map of Cultural Destinations in Minas Gerais State, Brazil and photo of Ouro Preto
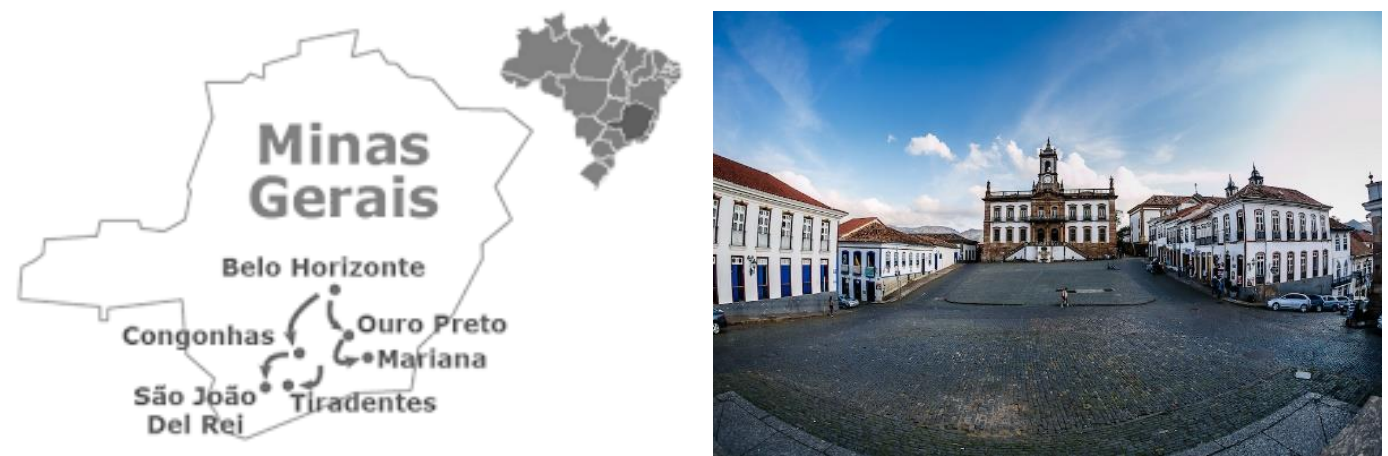

Source: http://www.brasilplanet.com.br and https://turismo.ouropreto.mg.gov.br/.

According to Ouro Preto's Competitiveness Index (Brasil, 2012), the destination stands out in the Cultural Aspects dimension (level five out of five), but it has a level three classification in Regional Cooperation, Public Policies, Marketing and Promotion, as well as in Tourism Services and Facilities. It also has a level four rating in Monitoring, Social Aspects, Tourist Attractions, Environmental Aspects, Business Capacity, Local Economy, Infrastructure, and Access. As such, the literature (Silva \& Brusadin, 2014; Coelho, Gosling, $\&$ Berbel, 2016) points out problems and challenges to promote tourism in the area.

This paper combines a stakeholders' view of tourist profiles with previous research and a survey on tourist profiles. It also identifies local problems and challenges for transforming Ouro Preto into an international tourist destination. The study aims to understand the marketing promotion activities and tourist profile of a local cultural tourism destination from the stakeholders' perspective.

The study's main contribution is its longitudinal analysis of the destination, which is still incipient in tourism research. Behnke, Seo, and Miller (2014) analyzed longitudinal data from 2002 to 2010 on students' evaluations of their study abroad programs in hospitality. Barnes, Mattsson, and Flemming Sørensen (2016) applied a longitudinal analysis by using the same survey instrument for tourists at three different moments: just before entry into the park, a day or two after their visit, and a month and a half after their visit. The present study used different research instruments to understand the same phenomenon, "destination marketing activities," in 2013 and 2019, in one particular cultural destination. The study also discusses possible ways to stimulate the development of Ouro Preto and other Brazilian destinations. 


\section{Literature review}

\section{Tourism and Stakeholders}

Tourism involves a complicated scenario with several groups of stakeholders (Sheehan, Ritchie, \& Hudson, 2007), each with their own particular interests and trajectories (Tkaczynski, Rundle-Thiele, \& Beaumont, 2009). The most frequently researched stakeholders include developers (tour operators, travel agencies, retailers, and hotels), government organizations (tourism councils), local communities (for example, residents), tourism-related service personnel (for example, tour guides), tourists themselves, and other related departments (for example, cultural relic protection departments), in addition to other investors and intermediaries (Zhong et al., 2019; Du Cros \& Kong, 2020). Among these stakeholders, government, hotels, and destination marketing organizations (DMOs) are the three most relevant to a destination (Sheehan, Ritchie, \& Hudson, 2007).

In different circumstances, stakeholders can establish different types of relationships and interactions (Wondirad, Tolkach, \& King, 2020). Stakeholder theory (Freeman, 1984) emphasizes the importance of collaboration and partnership between actors in order to achieve common goals. The assumption underlying this theory is that by capitalizing on collective intelligence and the ability of a system comprising different types of stakeholders, it will improve and transform in order to survive and achieve mutual success (Nyerere, Ngaruko, \& Mlozi, 2020). According to the aforementioned authors, several empirical studies use stakeholder theory to study and plan marketing strategies for tourist destinations.

All stakeholders operating at a given destination must use a consistent approach in order to survive in an increasingly competitive environment (Sheehan, Ritchie, \& Hudson, 2007; Tkaczynski, Rundle-Thiele, \& Beaumont, 2009).

Moreover, the concept of relationship with stakeholders is fundamental for the planning and management of tourist destinations (Pulido-Fernandez \& Merinero-Rodríguez, 2018). In this context, the relationship with stakeholders is understood as a set of non-uniform interactions between actors in the tourism sector at a specific destination (Wondirad, Tolkach, \& King, 2020). Collaborations between different stakeholders and their participation are fundamental to the success of developing sustainable tourism at a given destination, as they can facilitate the achievement of stakeholders' common goals (Zhong et al., 2019). Therefore, investigating the tourists' and stakeholders' perceptions of a destination's competitiveness is 
crucial to prioritize investments and promote product/service innovation (Stankov, Kennell, Morrison, \& Vujičić, 2019).

Given that a tourist destination is the site of a heterogeneous network of different stakeholders, establishing relationships between them is crucial (Pulido-Fernández \& Merinero-Rodríguez, 2018). The stakeholders need to be identified and relationships nurtured to ensure that their concerns, objectives, values, and responsibilities are understood and strategically synthesized (Robson \& Robson, 1996). Collaborative actions in this regard must be consistent and interdependent and driven by trust and reciprocity. They should result in effective and coordinated destination marketing management, guided by the safety and protection of the destination and visitors. They should improve the underlying infrastructure, provide a positive visitor experience, and strengthen the competitiveness of the destination in general, thus enhancing aggregate income (Wondirad, Tolkach, \& King, 2020).

\section{Destination marketing and hospitality}

Tourism as a field of study has undergone a number of strategic changes. These include marketing problems, technological advances, the consumer and supplier relationship approach, as well as sustainability (Kozak \& Andreu, 2006). Some studies have provided a global view of destination marketing research and identified the main related themes, such as tourist satisfaction, loyalty, branding, and product development (Hjalager, 2010). New technologies in tourism are also gaining visibility in related research, but the top priority in the industry is still to study consumer behavior (Oh, Kim, \& Shin, 2004; Bigné, 2005; Alcaniz, Simó, García, \& Herrera, 2008).

Hristov and Zehrer (2015) differentiate destination marketing from destination management. While destination marketing is considered to be outward looking, for instance direct marketing promotion to attract visitors, destination management has an inward focus, involving the discussion of topics such as destination competitiveness, resource management, and ensuring a welcoming experience for visitors. However, marketing promotion should not be the only activity carried out in the destination marketing approach. According to Medaglia and Silveira (2009), destination marketing studies can support tourism planning and its structuration, under the premises of public and private cooperation and destination sustainability and quality, so that the marketing promotion is more effective. 
A tourism destination needs resources and tourist attractions that provide symbols and images that present them to the public (Gunn, 1980). Besides the image of the destination, this set of resources should attract, create loyalty among, and satisfy tourists (McKercher, Denizci-Guillet, \& Ng, 2012). Stakeholders are key resources to achieve emotional bonds between tourists and the destination.

However, few studies have focused on destination marketing and its application. Within this context, there is no single product in which the producer has full control because the tourism product is composed of organizations of different sizes with diversified management (Baker \& Cameron, 2008). Complexity and interdependency among stakeholders results in local tourism marketing alliances (Palmer \& Bejou, 1995). Hence, the multidimensionality of destinations presents challenges for the application of tourism marketing. These challenges are related to the complexity of the tourism product offer and the number of stakeholders involved in the activity (Palmer \& Bejou, 1995), and especially to the fragmentation of ownership (Baker \& Cameron, 2008). Therefore, destinations are multi-layer systems (Hristov \& Zehrer, 2015).

Buhalis (2000) suggests the use of tourism destination marketing strategies as a coordination mechanism, with planning and management that provides gains for stakeholders. For this, successful destinations need to: effectively train human resources; cooperate with complementary tourist destinations and competitors to learn from them; and use innovation and marketing driven by research and technology. These elements help destination marketing managers in achieving their four strategic objectives:

1. To enhance the prosperity of long-term residents;

2. To enchant visitors while maximizing their satisfaction;

3. To maximize the profit of local companies and their multiplier effects;

4. To optimize the impacts of tourism by ensuring a sustainable balance between economic benefits and socio-cultural and environmental costs.

The role of individual destination actors, groups, networks, and organizations shape the future of destinations (Hristov \& Zehrer, 2015). Managers and stakeholders of destinations should prioritize three main activities when engaging in destination marketing: (1) identify and classify destination attractions, choosing how they will be offered to tourists; (2) measure the attractiveness of the destination and tourist attractions; and (3) use tools for managing the destination in a global and cohesive way (Coelho, 2015). The connection 
between government, society, and business is central to developing and managing destinations (Hristov \& Zehrer, 2015).

As it is not always possible to provide personalized messages for every tourist, segmentation is a strategy that can help managers to market a destination effectively (Tkaczynski \& Rundle-Thiele, 2019). Marketing campaigns should strengthen the destination brand by focusing on reasons for visiting (Hudson et al., 2019) and by understanding the heterogeneous behavior in the tourism sector (Pestana, Parreira, \& Moutinho, 2019).

One possible approach to tourism segmentation is to identify a tourist profile for a destination by using tourist surveys (Tkaczynski \& Rundle-Thiele, 2019). Another recommendation for marketing professionals to make tourists part of their marketing strategy is to transform the audience into brand ambassadors (Hudson et al., 2019). Understanding tourists' motivations, emotions, satisfaction, previous experiences, and intentions may help managers to design appropriate strategies and lead to economic growth (Pestana, Parreira \& Moutinho, 2019). This study contributes by showing another perspective on market segmentation by considering stakeholders as a whole and not only tourists.

\section{Method}

We used a mixed-method approach (Creswell, 2007) to achieve the study's goals. The first step was qualitative and aimed at understanding the dynamics of the destination and tourism promotion over the last six years. The second step was quantitative and aimed to identify the tourist profile of the destination. Finally, we triangulated the data to understand the destination marketing promotion activities. Figure 2 shows the research design and the processes used to obtain the research outputs. 
Figure 2 - Research Design Method

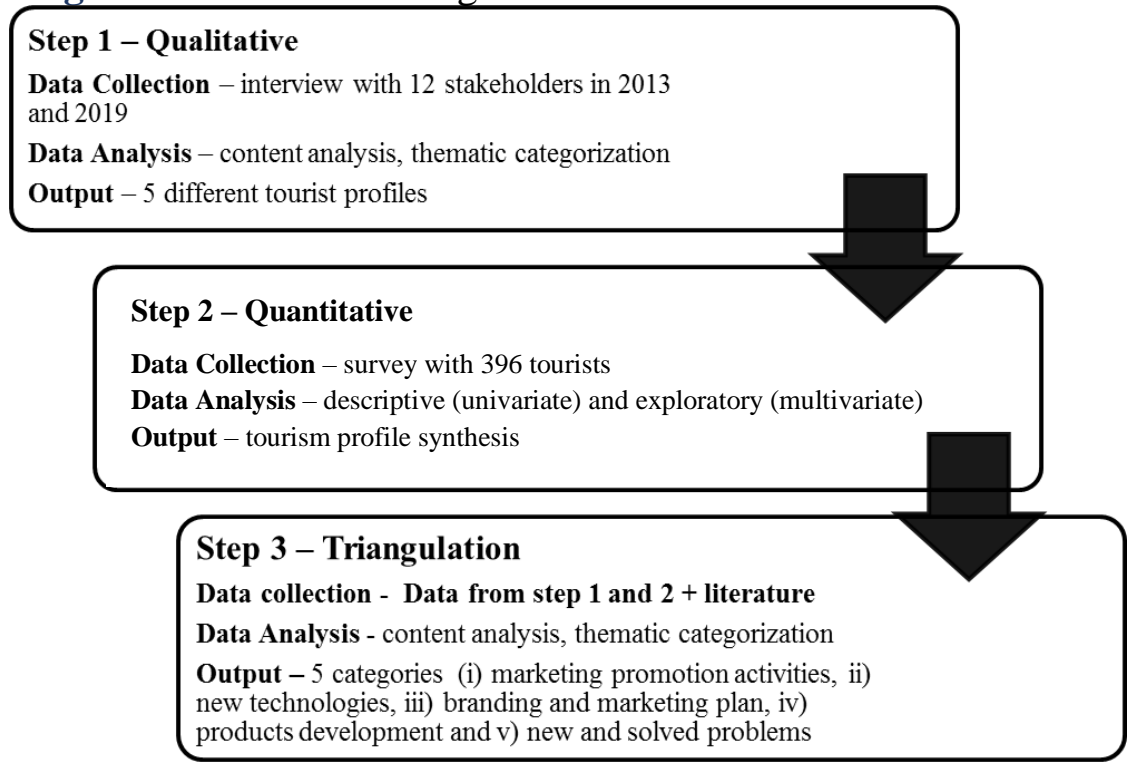

Source: The authors (2019).

\section{Qualitative Step}

We carried out the first round of interviews in 2013 and the second one in 2019, using similar approaches. It was essential to select stakeholders from distinct segments of local tourism. These stakeholders were directly connected to tourism activities, such as tour guides, entrepreneurs, hotel managers, artists, government managers, professors, and tourists.

We used a convenience snowball sampling technique to reach the interviewees, as used by Wang, Kirillova, and Lehto (2016). In 2013, the first stakeholder we interviewed was a tourism professor at the Federal University of Ouro Preto, in Minas Gerais. One of the authors scheduled all the interviews where the interviewee worked or lived. This gave us a better understanding of their habits and lifestyle and helped in making the interviewee feel more comfortable answering the questions. When this was not possible, we scheduled the interview in a local café or restaurant.

The face-to-face interview data collection occurred in two different time periods. The first interviews took place with 12 stakeholders in 2013, and the second round occurred in 2019. This approach was considered to be essential for understanding the dynamics of the destination and tourism promotion over the years (Table 1). 
Table 1 - Interviewed stakeholders in 2013 and 2019

\begin{tabular}{|c|c|c|c|c|}
\hline Stakeholder & Gender & 2013 & 2019 & Occupation \\
\hline 1 & M & $\mathrm{x}$ & & University Professor and Member of Tourism Council \\
\hline 2 & M & $\mathrm{x}$ & & Entrepreneur, Travel Agent \\
\hline 3 & $\mathrm{~F}$ & $\mathrm{x}$ & $\mathrm{x}$ & Hostel Manager \\
\hline 4 & M & $\mathrm{x}$ & $\mathrm{x}$ & Entrepreneur, Restaurant sector \\
\hline 5 & M & $\mathrm{x}$ & $\mathrm{x}$ & Photographer and Communicator \\
\hline 6 & M & $\mathrm{x}$ & & Graduation Student \\
\hline 7 & M & $\mathrm{x}$ & & Journalist \\
\hline 8 & M & $\mathrm{x}$ & & Government Agent, Entrepreneur, Restaurant Sector \\
\hline 9 & $\mathrm{~F}$ & $\mathrm{x}$ & $\mathrm{x}$ & Engineer and Tourism Researcher \\
\hline 10 & $\mathrm{~F}$ & $\mathrm{x}$ & $\mathrm{x}$ & Tourism Manager in a regional development organization \\
\hline 11 & $\mathrm{~F}$ & $\mathrm{x}$ & & Government Agent \\
\hline 12 & M & $\mathrm{x}$ & $\mathrm{x}$ & Local tourism Guide \\
\hline 13 & $\mathrm{~F}$ & & $\mathrm{x}$ & Local agency \& Hostel Manager \\
\hline 14 & M & & $\mathrm{x}$ & $\begin{array}{l}\text { Government Agent, Entrepreneur, Tourism Operations, } \\
\text { Communication, and Food \& Beverage Sectors }\end{array}$ \\
\hline 15 & $\mathrm{~F}$ & & $\mathrm{x}$ & Public Server, Tourism Agent \\
\hline 16 & M & & $\mathrm{x}$ & Entrepreneur, Hotel Sector, Tourism Student \\
\hline 17 & M & & $\mathrm{x}$ & Tourism Guide, Musician \\
\hline
\end{tabular}

Source: The Authors (2019).

The semi-structured script from the first round (2013) included the following questions:

1. What is your relationship with Ouro Preto? Explain a little about your history with this city.

2. How do you imagine that Ouro Preto is viewed by people who have never been here?

3. What unique attractions do you think that Ouro Preto offers?

4. What do tourists look for when visiting Ouro Preto (motivations, places to visit, characteristics they like)?

5. What are the problems Ouro Preto has to address to attract tourists?

And the second round (2019) was condensed mainly into three questions:

1. How has your relationship with Ouro Preto changed from 2013 up to now?

2. How have tourism activities changed from 2013 up to now?

3. What do you think still needs to change in Ouro Preto as a tourism destination?

One of the authors was responsible of scheduling and conducting the interviews with the same stakeholders. In 2019, of the 12 stakeholders previously interviewed, the researchers were able to reach seven of them through email, telephone, or the stakeholders' network. Hence, the researchers looked for new interviewees with similar social roles to sustain the longitudinal approach (Hristov \& Zehrer, 2015). These stakeholders nominated five new stakeholders through snowball sampling, which updated our database. The six-year gap was considered essential to identify changes and innovations in the destination marketing and management. According to the city website, the hotel occupancy rate was $44 \%$ in 2013 and remained the same in 2017 (the year for which the most recent data are available). Meanwhile, the competitiveness index was measured as level 4 out of 5, rising slightly from 
64.3 points out of 100 in 2013 to 69.3 in $2015 .{ }^{1}$ This suggests that tourism had developed slowly in the region, but in 2019 the interviews suggested that tourism was gaining more attention from the local government, because mining activities had decreased in 2019.

All the interviews were recorded and lasted from 18 minutes to 1 hour and 20 minutes. We then carried out the qualitative step to understand the stakeholders' perception of Ouro Preto's tourist profile. Longitudinal studies can seek to capture the use of management tools in destinations over time (Hristov \& Zehrer, 2015) and here we aimed for a comparative analysis. Content analysis (Bardin, 2008) drove the qualitative data analysis. The stakeholders indicated four tourist profiles, as described in the results.

\section{Quantitative step}

The second step involved a survey to understand the tourists' profiles. The survey was self-completed by 396 respondents who were visiting the city and were older than 18 . To collect the data, a research team was trained to approach the tourists and orient their answers to the survey. The research team applied the survey at local attractions in the city, such as next to churches and museums, from May to July of 2013.

We categorized the socio-demographic and behavioral data captured by the survey to analyze the tourists' profiles, using univariate (simple and relative frequency) and multivariate (multiple correspondence) analyses. The variables and their respective categories are presented in Table 2 .

Table 2 - Research variables and respective categories

\begin{tabular}{l|l|l|l}
\hline \multicolumn{1}{c|}{ Variables } & \multicolumn{1}{|c}{ Categories } & \multicolumn{1}{c}{ Variables } & \multicolumn{1}{c}{ Categories } \\
\hline Gender & Male & Origin & Domestic \\
International
\end{tabular}

\footnotetext{
${ }^{1}$ Data available at: https://turismo.ouropreto.mg.gov.br/pesquisas. Accessed on 02/24/2021.
} 


\begin{tabular}{|c|c|c|c|}
\hline & $\begin{array}{l}\text { High school complete } \\
\text { High School incomplete } \\
\text { College incomplete } \\
\text { College complete } \\
\text { Post-Graduation incomplete } \\
\text { Post-Graduation complete }\end{array}$ & & $\begin{array}{l}\text { Conclusão } \\
\text { Friends \& Relatives } \\
\text { Still deciding } \\
\text { Fraternity }\end{array}$ \\
\hline $\begin{array}{l}\text { Income } \\
\text { monthly) }\end{array}$ & $\begin{array}{l}\text { Up to } 120 \\
\text { From } 120 \text { to } 300 \\
\text { From } 300 \text { to } 600 \\
\text { From } 600 \text { to } 900 \\
\text { From } 900 \text { to } 1200 \\
\text { From } 1200 \text { to } 1500 \\
\text { From } 1500 \text { to } 2000 \\
\text { Over } 2000\end{array}$ & Total Trip Expenditure & $\begin{array}{l}\text { Up to } 10 \text { USD } 69 \\
10-20 \text { USD } 140 \\
20-60 \text { USD } 130 \\
60-100 \text { USD } 40 \\
\text { Over } 100 \text { USD }\end{array}$ \\
\hline
\end{tabular}

Source: The authors (2019).

Multiple correspondence analysis is used when researchers want to explore associative behaviors between three or more categorical variables and between the categories of each of them and determine the coordinates of the categories in order to construct perceptual maps (Fávero \& Fávero, 2015). A perceptual map is a visual representation of an individual's perceptions in two or more dimensions. Normally, this map has opposite levels of dimensions on the $\mathrm{x}$ and $\mathrm{y}$ axes (Hair, 2014).

The map was useful in identifying and inferring how the different tourists in the city of Ouro Preto are grouped, considering the motivations for their trip, the duration of their trip, and the origins of the tourists. Based on the confluence of qualitative and quantitative data, we were able to identify and synthesize the profile of tourists who passed through the city during the survey period. To support the data analysis, we used the Stata software, version 14.

\section{Triangulation}

As a final step, we compared the qualitative and quantitative data, as triangulation requires at least two different points of observation of the research issue (Ingram, Caruana, \& McCabe, 2017). The content analysis followed three steps. First, a body of text was defined for evaluation. This study was based on the transcript from two sets of interviews with stakeholders of Ouro Preto.

The second step consisted of identifying the themes. Themes that were either repeated by many stakeholders or were unique were identified through a careful review of the text. Therefore, we choose a posteriori themes in this step. Many revisions took place in this second step in order to achieve the third step. The final step aimed at reaching a consensus on the essential themes raised by the stakeholders and tourists over time and contrasting them with previous literature. 
We found and discussed five main categories: i) marketing promotion activities, ii) new technologies, iii) branding and marketing plan, iv) product development, and v) new and solved problems. These themes helped to develop our discussion.

\section{Results}

This section presents the univariate and multivariate analyses used to characterize the tourists' profiles and marketing and destination management activities.

\section{Tourists' profiles}

The survey data details some of the tourists' profiles. Only 3\% were international tourists and the majority was leisure and young single travelers (Table 3).

Table 3 - Tourists' Profile of Ouro Preto, Minas Gerais, Brazil

\begin{tabular}{|c|c|c|}
\hline \multicolumn{3}{|c|}{ Tourists' Profile of Ouro Preto, Brazil } \\
\hline Origin & Income (USD monthly) & Scholar Degree \\
\hline Domestic $373(94,2 \%)$ & Up to $1202(0,5 \%)$ & Elementary incomplete $7(1,8 \%)$ \\
\hline International $12(3 \%)$ & From 120 to $30038(9,6 \%)$ & Elementary complete $11(2,8 \%)$ \\
\hline \multirow[t]{2}{*}{ Missing $11(2,8 \%)$} & From 300 to $60076(19,2 \%)$ & High school complete $11(2,8 \%)$ \\
\hline & From 600 to $90078(19,7 \%)$ & High School incomplete $47(11,9 \%)$ \\
\hline Gender & From 900 to $120064(16,2 \%)$ & College incomplete $109(27,5 \%)$ \\
\hline Male $166(41,9 \%)$ & From 1200 to $150042(10,6 \%)$ & College complete $86(21,7 \%)$ \\
\hline Female $226(57,1 \%)$ & From 1500 to $200039(9,8 \%)$ & Post-Graduation incomplete $32(8,1 \%)$ \\
\hline \multirow[t]{2}{*}{ Missing $4(1,0 \%)$} & Over $200049(12,4 \%)$ & Post-Graduation complete $92(23,7 \%)$ \\
\hline & Missing $8(2,1 \%)$ & Missing $1(0,3 \%)$ \\
\hline Age & Trip Motivation & Trip Duration \\
\hline $18-2033(8,3 \%)$ & Leisure/vacation $278(70,2 \%)$ & 1 day $185(46,7 \%)$ \\
\hline $21-30192(48,5 \%)$ & Events $41(10,4 \%)$ & 2 days $83(21,0 \%)$ \\
\hline $31-4085(21,5 \%)$ & Education $25(6,3 \%)$ & 3 days $55(13,9 \%)$ \\
\hline $41-5052(13,1 \%)$ & VFR $16(4 \%)$ & 4 days $32(8,1 \%)$ \\
\hline $51-6024(6,1 \%)$ & Business $10(2,5 \%)$ & 5 days $21(5,3 \%)$ \\
\hline $61-702(0,6 \%)$ & Others $21(5,3 \%)$ & 6 days $3(0,8 \%)$ \\
\hline $71+2(0,6 \%)$ & Missing $5(1,3 \%)$ & 7 days $7(1,8 \%)$ \\
\hline \multirow[t]{2}{*}{ Missing $6(1,5 \%)$} & & $7+$ days $5(1,4 \%)$ \\
\hline & & Missing $(1,3 \%)$ \\
\hline Marital Status & Lodging & Total Trip Expenditure \\
\hline Single $238(60,1 \%)$ & Hotel/Lodge $180(45,5 \%)$ & Up to 10 USD $69(17,4 \%)$ \\
\hline Married $131(33,1 \%)$ & None $149(37,6 \%)$ & $10-20$ USD $140(35,4 \%)$ \\
\hline Divorced $21(5,3 \%)$ & Friends \& Relatives $42(10,6 \%)$ & 20- 60 USD $130(32,8 \%)$ \\
\hline Widower $2(0,5 \%)$ & Still deciding $7(1,8 \%)$ & 60- 100 USD $40(10,1 \%)$ \\
\hline Other $3(0,8 \%)$ & Fraternity $7(1,8 \%)$ & Over 100 USD $14(3,5 \%)$ \\
\hline \multirow[t]{2}{*}{ Missing $1(0,3 \%)$} & Other $7(1,8 \%)$ & \\
\hline & Missing $4(1,0 \%)$ & \\
\hline
\end{tabular}

Notes: VFR= Visiting friends and Relatives. For this research we used 1USD = 5BRL.

Source: Survey data (2019), n=396. 
After verifying the existence of a statistically significant association between the variables trip motivation, trip duration, and origin and identifying the dependency relationships between their categories, it was possible to generate a graphical representation of these associations through the perceptual map shown in Figure 3. In the perceptual map, each quadrant gathers the groups' characteristics according to their travel motivations, trip duration, and origin.

Figure 3 - Perceptual Map

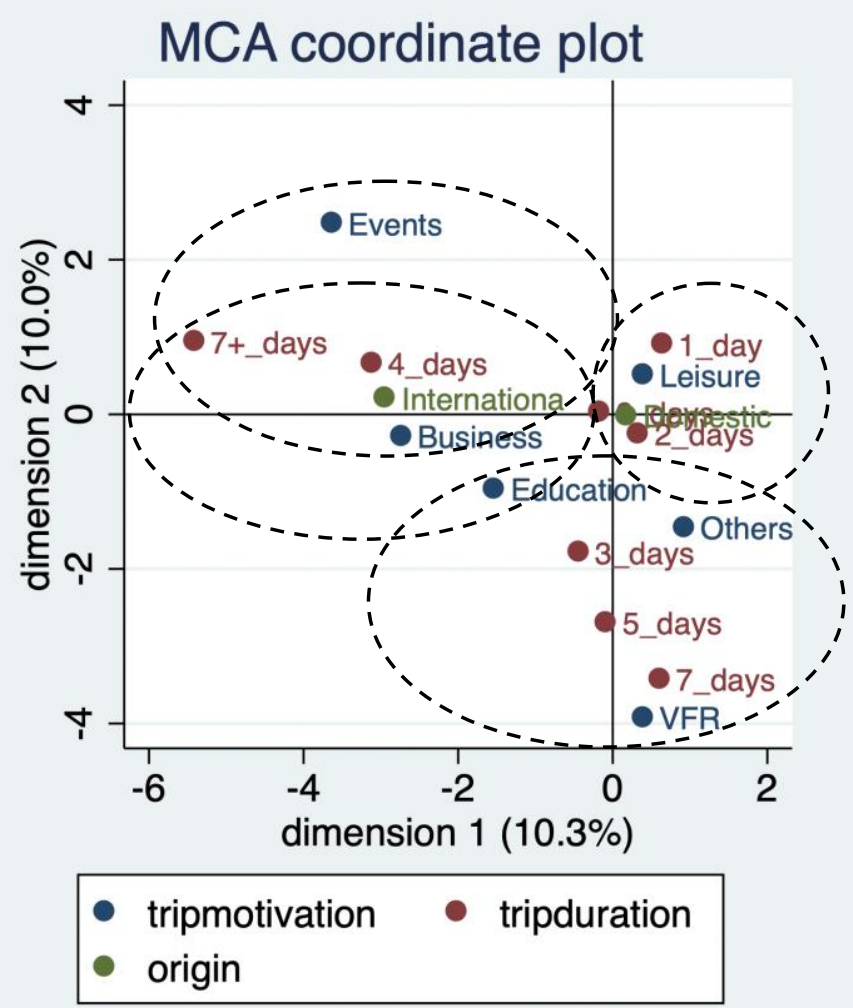

coordinates in standard normalization

Source: Research's data

The results of the exploratory analysis pointed to the formation of four subgroups. By cross-referencing these data with the information from the interviews, especially regarding the question "What do tourists look for when visiting Ouro Preto?", we were able to confirm the stratification of the profile of tourists in the city of Ouro Preto in the period analyzed, classifying them into four groups. The categorization is defined based on the perception of the stakeholders interviewed. 
According to the stakeholders, there are at least four types of tourists in Ouro Preto: 1) historical/cultural tourists, 2) fraternity tourists, 3) regional visitors, and 4) international tourists.

Table 4 - Tourist's Profile according to stakeholder's perception

\begin{tabular}{ll}
\hline Tourist Segment & Stakeholders' responses \\
\hline Historical/ Cultural Tourists & "I see here a more intellectualized, more cultural tourist. Here we do not \\
& have a beach, where we do not have entertainment. "Stakeholder H \\
& "The tourist who goes to Ouro Preto, for me, he is seeking history and \\
culture." Stakeholder J
\end{tabular}

Fraternity Tourists

Regional Tourists

International Tourists

\begin{abstract}
"Many tourists stay in the fraternity houses too. Others are staying at the hotel. It varies with the type of tourist. Some people prefer revelry and stay here [in the frat]. Frat Carnival is cool. "Stakeholder F

"There is the public that is looking for a party, which is the young people, even because of the history of the fraternities there." Stakeholder $\mathbf{J}$
\end{abstract}

\begin{abstract}
"Many people, I do not think they even go into the churches. Nor do they enter museums. I think many people come to spend the day here and just walk in the streets. So, it's a relationship even with something of their imagination of the country cities. " Stakeholder I
\end{abstract}

Source: The Authors (2019).

Regional tourists visit the city for leisure and for shorter periods (1 to 2 days); they are usually just passing through. Fraternity tourists are generally young students and usually stay in fraternities for periods of 3 to 7 days, taking advantage of academic events to socialize at the student residences. Historical/cultural tourists are motivated to visit the city due to the events held and usually spend 4 to 7 days in the city. Finally, international tourists (much fewer in number) also spend between 4 and (sometimes more than) 7 days, and the reason for their visit involves business, education, and culture (on a lesser scale). 


\section{Destination marketing and management}

The main findings from the longitudinal interviews and survey can be grouped into five areas: i) marketing promotion activities, ii) new technologies, iii) branding and marketing plan, iv) product development, and v) new and solved problems.

\section{Marketing promotion activities}

There was massive promotion in the $1980 \mathrm{~s}$, but nowadays, not much is done internationally. The stakeholders highlighted the lack of a marketing plan in 2013 and 2019. Many of the stakeholders recognized that marketing promotion is a priority, and some locals think "the destination is ready" to receive tourists. On the other hand, others pointed out that much still needs to be done, including elaborating a marketing plan and segmentation.

One managerial implication of this study is that it suggests organizing specific tours and products for each of the four tourist profiles. Nevertheless, the municipal tourism secretary states that it is not their responsibility to do this and that the private sector should provide this type of service in order to avoid favoring one particular brand.

\section{New technologies}

New technologies (Kozak \& Andreu, 2006) and advances in information and communication technologies are described in the tourism literature (Buhalis \& Law, 2008; Law, Buhalis, \& Cobanoglu, 2014). The stakeholders mentioned that new promotion activities have been developed in the destination based on the internet and mobile technologies, especially regarding communication with tourists. Social networks, applications, and websites have helped with the supply and distribution of new products such as Airbnb, local experiences, and events.

The study indicates that destination management has developed in the last six years, and some stakeholders have started measuring their marketing promotion via the internet through social engagement and the use of hashtags.

\section{Branding and Marketing Plan}

There is a new tourism plan, but a marketing strategy plan is still needed to leverage destination marketing. 
The Tourism Secretary has presented a destination brand and a formal document guiding how it should be used. However, this brand is not used by local websites and establishments. As stated by Gunn (1980), destinations need to provide symbols and images that present them to the public. It may be that the stakeholders do not recognize this brand as one that represents the destination.

\section{Products Development}

Product innovation refers to the implementation and commercialization of ideas and collaborative elements that are essential to acquire competencies (Hjalager, 2010). The tourists in Ouro Preto perceive five different attractions: the environment (locals, employees, safety, cost-benefit, and cleanness), infrastructure (access, basic infrastructure), tourism resources (information, events, accommodation, and gastronomy), history, and museums (Coelho \& Gosling, 2017).

New products have been developed (new areas that are being discovered by tourists, new establishments) and other products have still to be implemented. The stakeholders mentioned new restaurants, new bars, and new tourism policies. Some regions and attractions in Ouro Preto and its districts remain underexplored, but are more popular among tourists now. Examples include a local district called "Lavras Novas," which has been paved and is visited on a city tour on antique buses.

In addition, new experiences were mentioned by the stakeholders in 2019 that did not exist in 2013. For instance, a destination photograph experience and food and beverage experiences were mentioned by the stakeholders. The various types of tourism experiences provide a useful starting point for a wide variety of additional work on understanding the way visitors evaluate and enjoy tourism experiences (Ritchie, Tung, \& Ritchie, 2011).

\section{New and Solved Problems}

Some of the problems listed by the stakeholders in 2013 were traffic, a lack of integration in the tourism trade, and the absence of a solid destination marketing proposal and its implementation. In the survey the tourists wrote about some of the problems at the destination, such as traffic and a lack of accessibility, parking spaces, tourist signs, maps, and restaurants. 
Regarding employees, some of the tourists said that there was a lack of bilingual employees and that some local guides were impatient. Local studies also reinforce these results (Coelho \& Gosling, 2015; Coelho, Gosling, \& Berbel, 2016). These employee and guide problems confirm the need to train human resources effectively, as indicated by Buhalis (2000).

Some of the problems identified in 2013 were solved (garbage, tourist signs, stakeholders' involvement and action) (Coelho, Gosling, \& Berbel, 2016). Others continue (traffic and parking, lack of accessibility, human resources and guide training) and there are also new ones (lack of governmental resources, unemployment, and a destination brand that is not used). The issues and problems for the development of tourism are similar to those mentioned in international literature: a "poor tourism policy (such as positioning, coordination, and investment), a lack of government support, a narrow perspective, a high level of corruption, and broad political instability" (McLennan, Ruhanen, Ritchie, \& Pham, 2012: 176).

\section{Discussion}

The longitudinal approach used helped in identifying the development of tourism in the area. Hosts agreed that tourism was an important activity for the local economy. A crucial difference between 2013 and 2019 was that tourism has started to be accepted as a real economic vocation of the city, while industrial activities such as mining provide fewer funds for the government. According to McLennan, Ruhanen, Ritchie, and Pham (2012), the development of tourism destinations involves the development of institutions, practices, and more extensive processes. Therefore, the promotion and development of destinations strengthens local groups, institutions, and stakeholders.

The main developments in Ouro Preto as a tourism destination and the problems that persist, according to the stakeholders, are outlined in Figure 4.

Figure 4 - Main differences in tourism destination management

\begin{tabular}{ll}
\hline Main developments from 2013 to 2019 & Challenges which persist in 2019 \\
\hline - Tourism as a natural economic vocation & $\bullet$ Lack of a Marketing Plan \\
- Network strengthens & - Small fragmented and discontinuous projects \\
- Stronger hosts' participation & $\bullet$ Economic crisis \\
- New products and experiences' development & - Social problems (health, unemployment) \\
$\quad$ (in Ouro Preto and region) &
\end{tabular}

Source: The authors (2019). 
In terms of tourists' needs and desires, the findings are coherent with those of previous research. While some recent papers discuss over-tourism (Oklevik et al., 2019) and its implications, international tourists in Ouro Preto represent only 3\% of all tourists and involve excursionists who intend to spend less than 100 USD on their whole trip.

The central argument is that although the destination has renamed its attractions, stakeholders need to work together to innovate and provide novelty and surprises for excursionists and international travelers, without forgetting the local people (residents, employees, hosts, and guests). Positive changes for a local destination involve quality of life and the experience that both hosts and guests receive, such as better infrastructure, more knowledgeable staff, and higher quality services (Byrd, 2007).

Regarding segmentation, the destination marketing organizations also seem to lack resources and specific policies to target the seniors' market. The competition to attract this market is intensifying in developing countries such as the Philippines, Malaysia, and Thailand, which provide benefits such as health care discounts and tax breaks (Hudson, Fung So, Li, Meng, \& Cárdenas, 2019). Offering personalized experiences for travelers can enhance the relationship between destinations and tourists (Corrêa \& Gosling, 2020).

Tkaczynski and Rundle-Thiele (2019) also point to empty nesters (couples over 50 years old with no children) and families as possible targets for segmentation in Australia, because they tend to stay longer at destinations (up to two weeks). However, it seems that few attractions in Ouro Preto are geared towards families, seniors, and empty nesters due to mobility and access constraints in the city. The establishments should develop special products to attract this public, but they should also consider the local community as possible customers. Managers should pay attention to leisure, knowledge, and socialization (Pestana, Parreira, \& Moutinho, 2019) when developing these products.

The literature shows that for a positive tourism transformation to occur, destinations require research, an effective tourism policy, education, training, and performance measurements (McLennan et al., 2012). Moreover, to start promoting Ouro Preto properly, the stakeholders should identify, develop, and use a unique brand identity, by consistently using a community brand in promotional materials. Santos and Silva (2015) indicate that regional cooperation and governance can help to improve destinations. Finally, promotion actions should be carried out by professionals, with the participation of stakeholders and a segmented focus. 


\section{Final remarks}

Brazil as a whole seems to have destination marketing and management problems and not only in specific cities such as Ouro Preto. Opportunities to offer a better quality of life for local stakeholders and tourists are being missed by not addressing simple problems such as traffic and security and by not providing innovative and segmented products. Moreover, investigating stakeholders could provide insights into how the trade could surprise tourists by developing new hospitality programs.

Organizing and creating a respectable city for stakeholders themselves should be a tourism board's main action to promote a tourism destination. Tourism activities are only meaningful if they enhance society and the local community. This may be the most challenging element to achieve as tourism is a social practice that features on the same agenda as health, education, safety, and social assistance in Brazil. Therefore, for tourism to become a central matter for the government, that government must address basic social problems. In the long run, this provides a safer destination with a better-educated population, meaning tourism agents will be more prepared to deal with the multiple offers tourism provides. Moreover, instead of seeing it as merely an economic activity, tourism must be understood as a key activity to develop regions and enhance the identity and authenticity of places .

Another managerial implication of this study is that it identifies segments and the value provided for the tourists who visit the destination. Academics, researchers, and government should use a solid basis for decision-making based on data rather than on intuition. In this respect, the variables motivation for travel, length of stay, and origin of tourists help understand the profile of tourists in Ouro Preto and may indicate strategies for the management of tourism in that region. Furthermore, when constructing marketing plans, one should ask: How do customers see a destination? What products are they interested in? What are their main fears and curiosities? When they come, what do they like or dislike? Understanding tourists' behavior is key to adding value to tourism activities. When the "right places" are promoted to the "right public," the chances of succeeding are higher.

Another important managerial step is to propose and invest in integrated marketing campaigns. There is no other way to choose and invest in products and promote routes that are more prepared to receive tourists. For instance, investment in integrated tourism planning with a solid message that incorporates traditional and social media marketing could help deliver powerful messages to the potential public and generate positive intentions to visit 
Brazilian destinations. The experience itself is important in providing personal perceptions of Brazilian culture, gastronomy, and the environment. The local tourism trade must be prepared to evoke emotions and plan sensorial experiences for customers.

As for the study's limitations, although it used snowball sampling for the qualitative step, we are unable to generalize the results. This is also true for the survey, which used nonprobabilistic data collection. Future research should include other historical cities and crosscountry studies to enrich the discussion. Using examples of destinations that are experiencing different processes such as over-tourism could enhance comparative studies in the field.

Further investigations would be useful to clarify the challenges of the industry and provide guidance for attending to each of the tourist profiles with specific products and segmentation. This research could also help in defining an agenda for Brazilian public policies and actions to attract the international market.

\section{References}

Alcaniz, J. E., Simó, L. A., García, I. S., \& Herrera, A. A. (2008). Investigación internacional en marketing turístico: análisis de contenido sobre temas y metodologias. PASOS - Revista de Turismo e Patrimônio Cultural, 6(3), 391-398.

Baker, M. J., \& Cameron, E. (2008). Critical Success Factors in Destination Marketing. Tourism and Hospitality Research, 8(2), 79-97.

Bardin, L. (2008). Análise de conteúdo (4th ed.). Lisboa: Edição 70.

Barnes, S. J., Mattsson, J., \& Flemming Sørensen. (2016). Remembered experiences and revisit intentions: A longitudinal study of safari park visitors. Tourism Management, 57, 286-294.

Behnke, C., Seo, S., \& Miller, K. (2014). Enhancing the study abroad experience: A longitudinal analysis of hospitality-oriented, study abroad program evaluations. Tourism Management, 42, 271-281. https://doi.org/10.1016/j.tourman.2013.12.010

Bigné, E. (2005). Nuevas orientaciones del marketing turístico: de la imagen de destinos a la fidelización de los turistas. Papeles de Economía, Especial Monográfico, 102, 221-235.

BRASIL. (2012). Caracterização e dimensionamento do turismo doméstico no Brasil 2010/2011. São Paulo: FIPE.

Buhalis, D. (2000). Marketing the Competitive Destination of the Future. Tourism Management, 21(1), 97-116. 
Buhalis, Dimitrios, \& Law, R. (2008). Progress in information technology and tourism management: 20 years on and 10 years after the Internet-The state of eTourism research. Tourism Management, 29(4), 609-623. https://doi.org/10.1016/j.tourman.2008.01.005

Byrd, E. T. (2007). Stakeholders in Sustainable Tourism Development and their Roles : Applying Stakeholder Theory to Sustainable Tourism Development. Tourism Review, 62(2), 6-13.

Coelho, M. F., \& Gosling, M. S. (2017). Factores de Atractividad Turística Percibida: Impactos en la reputación del destino y en la intención de recomendarlo a través de Internet. Estudios y Perspectivas En Turismo, 26(3), 509-530.

Coelho, M. F. (2015). O que Atrai o Turista? Gestão da Competitividade de Destinos a Partir de Atrações e da Atratividade Turística. Rosa dos Ventos, 7(4), 489-505.

https://doi.org/http://dx.doi.org/10.18226/21789061.v7iss4p489

Coelho, M. F., \& Gosling, M. (2015). Comentar bem ou mal na internet? O engajamento de viajantes em Reviews de Hotéis. Turismo y Desarrollo local sostenible, 19, 1-14.

Coelho, M. F., Gosling, M. S., \& Berbel, G. (2016). Atratividade de destino turístico: a percepção dos atores locais de Ouro Preto, MG, Brasil. PASOS - Revista de Turismo e Patrimônio Cultural, 14(4), 929-947.

Corrêa, S. C. H. \& Gosling, M. S. (2020) Destinos turísticos inteligentes na avaliação de pesquisadores e de profissionais do turismo nos setores público e privado. Revista Hospitalidade, 17(2), 71-94. Doi: https://doi.org/10.21714/2179- 9164.2020.v17n2.005

Creswell, J. W. (2007). Projeto de Pesquisa: Métodos qualitativo, quantitativo e misto. Porto Alegre: Atmed.

Dolnicar, S. \& Ring, A. (2014). Tourism Marketing Research: Past, Present and Future. Annals of Tourism Research, 47, 31-47.

Du Cros, H., \& Kong, W. H. (2020). Congestion, popular world heritage tourist attractions and tourism stakeholder responses in Macao. International Journal of Tourism Cities.

Falkner, B. H. W. (2001). Desenvolvimento de abordagens estratégicas ao marketing de destino turístico: A experiência da Austrália. In W. F. Theobald (Ed.), Turismo Global. (pp. 311-328). São Paulo: Senac.

Fávero, L., \& Fávero, P. (2015). Análise de Dados: Técnicas multivariadas exploratórias com SPSS e Stata. Elsevier Brasil.

Flores, L. C. S., Cavalcante, L. S. \& Raye, R. L. (2013) Marketing turístico: Estudo sobre o uso da tecnologia da informação e comunicação nas agências de viagens e turismo de Balneário Camboriú (SC, Brasil). Revista Brasileira de Pesquisa em Turismo, 6 (3), 322 339.

Freeman, R. E. (1984). Strategic management: A stakeholder approach. Boston: Pitman. 
Gunn, C. A. (1980). Amendment to Leiper: The Framework of Tourism. Annals of Tourism Research, 7(2), 235-255.

Hair, J. F. (Ed.). (2014). Multivariate data analysis (7. ed., Pe). Harlow: Pearson.

Hjalager, A. M. (2010). A review of innovation research in tourism. Tourism Management, 31(1), 1-12. https://doi.org/10.1016/j.tourman.2009.08.012

Hristov, D., \& Zehrer, A. (2015). The destination paradigm continuum revisited: DMOs serving as leadership networks. Tourism Review, 70(2), 1-23.

https://doi.org/dx.doi.org/10.1108/TR-08-2014-0050

Hudson, S., Fung So, K. K., Li, J., Meng, F., \& Cárdenas, D. (2019). Persuading tourists to stay - Forever! A destination marketing perspective. Journal of Destination Marketing and Management, 12(february), 105-113. https://doi.org/10.1016/j.jdmm.2019.02.007

Ingram, C., Caruana, R., \& McCabe, S. (2017). PARTicipative inquiry for tourist experience. Annals of Tourism Research, 65(july), 13-24. https://doi.org/10.1016/j.annals.2017.04.008

Kozak, K., \& Andreu, L. (2006). Progress in Tourism Research. Amsterdam: Elsevier.

Law, R., Buhalis, D., \& Cobanoglu, C. (2014). Progress on information and communication technologies in hospitality and tourism. International Journal of Contemporary Hospitality Management, 26(5), 727-750. https://doi.org/10.1108/IJCHM-08-2013-0367

McKercher, B., Denizci-Guillet, B., \& Ng, E. (2012). Rethinking Loyalty. Annals of Tourism Research, 39(2), 708-734.

McLennan, C., Ruhanen, L., Ritchie, B., \& Pham, T. (2012). Dynamics of Destination Development. Journal of Hospitality \& Tourism Research, 36(2), 164-190. https://doi.org/10.1177/1096348010390816

Medaglia, J., \& Silveira, C. (2009). La evolución del marketing de destinos. Estudios y Perspectivas En Turismo, 18(5), 530-545.

Nyerere, V. C. Y., Ngaruko, D., \& Mlozi, S. (2020). The Mediating Role of Strategic Planning on the Determinants of Sustainable Urban Tourism: Empirical Evidence from Tanzania. African Journal of Economic Review, 8(1), 198-216.

Ocke, M.A.M \& Ikeda, A.A. (2013) Marketing de lugares: os recifes artificiais multifuncionais como proposta de atração turística. Revista Brasileira de Pesquisa em Turismo, 7 (3), $496-512$.

Oh, H., Kim, B., \& Shin, J. (2004). Hospitality and Tourism marketing recent developments in research and future directions. International Journal of Hospitality Management, 23(5), 425-477. 
Oklevik, O., Gössling, S., Michael, H., Kristian, S., Petter, G. \& McCabe, S. (2019). Overtourism, optimization, and destination performance indicators: a case study of activities in Fjord Norway, Journal of Sustainable Tourism, 27(12), 1804-1824. DOI: 10.1080/09669582.2018.1533020.

Palmer, A., \& Bejou, D. (1995). Tourism destination marketing alliances. Annals of Tourism Research, 22(3), 616-629.

Pestana, M. H., Parreira, A., \& Moutinho, L. (2019). Motivations, emotions and satisfaction: The keys to a tourism destination choice. Journal of Destination Marketing and Management, (April), 1-9. https://doi.org/10.1016/j.jdmm.2018.12.006

Pike, S. (2005). Tourism destination branding complexity. Journal of Product \& Brand Management, 14(4), 258-299.

Plog, S. (2001). Why Destination Areas Rise and Fall in Popularity: An Update of a Cornell Quarterly Classic. Cornell Hotel and Restaurant Administration Quarterly, 42(3), 13-24.

Pulido-Fernández, J. I., \& Merinero-Rodríguez, R. (2018). Destinations' relational dynamic and tourism development. Journal of Destination Marketing \& Management, 7, 140-152.

Ritchie, J. R. B., Tung, V. W. S., \& Ritchie, R. J. B. (2011). Tourism experience management research: Emergence, evolution and future directions. International Journal of Contemporary Hospitality Management, 23(4), 419-438.

https://doi.org/10.1108/09596111111129968

Robson, J., \& Robson, I. (1996). From shareholders to stakeholders: critical issues for tourism marketers. Tourism Management, 17(7), 533-540.

Santos, G. E. \& Silva, V. J. (2015) Mapa perceptual como ferramenta para a análise da imagem do destino. Revista de Turismo Contemporâneo, 3(2), 211-231.

Silva, G. P. C. \& Brusadin, L. B. (2014). Os espaços da hospitalidade e as representações da mineiridade nas repúblicas estudantis de Ouro Preto (MG). Cenário, 2(2), 140-161.

Sheehan, L., Ritchie, J. B., \& Hudson, S. (2007). The destination promotion triad: Understanding asymmetric stakeholder interdependencies among the city, hotels, and DMO. Journal of Travel Research, 46(1), 64-74.

Stankov, U., Kennell, J., Morrison, A. M., \& Vujičić, M. D. (2019). The view from above: the relevance of shared aerial drone videos for destination marketing. Journal of Travel and Tourism Marketing, 36(7), 808-822. https://doi.org/10.1080/10548408.2019.1575787

Théry, H. (2015). Lugares e fluxos do turismo nacional brasileiro, Via [En ligne], 7, mis en ligne le 01 juillet 2015, consulté le 07 avril 2020. URL:

http://journals.openedition.org/viatourism/572; DOI: https://doi.org/10.4000/viatourism.572 
Tkaczynski, A., \& Rundle-Thiele, S. (2019). Is destination marketing missing the mark? A Fraser Coast segmentation analysis. Journal of Destination Marketing and Management, 12(February), 12-14. https://doi.org/10.1016/j.jdmm.2019.02.001

Tkaczynski, A., Rundle-Thiele, S. R., \& Beaumont, N. (2009). Segmentation: A tourism stakeholder view. Tourism Management, 30(2), 169-175.

Wang, S., Kirillova, K., \& Lehto, X. (2016). Travelers' food experience sharing on social network sites. Journal of Travel \& Tourism Marketing, 1(Sep), 1-14. https://doi.org/10.1080/10548408.2016.1224751

Wondirad, A., Tolkach, D., \& King, B. (2020). Stakeholder collaboration as a major factor for sustainable ecotourism development in developing countries. Tourism Management, 78, 104024.

Zhong, L., Sun, S., Law, R., \& Zou, T. (2020). Stakeholders' perceptions of heritage tourism sites development in China. Tourism Recreation Research, 45(1), 132-138. 